(c) American Dairy Science Association, 2006.

\title{
Production of Pure Holsteins Versus Crossbreds of Holstein with Normande, Montbeliarde, and Scandinavian Red
}

\author{
B. J. Heins, L. B. Hansen, and A. J. Seykora \\ Department of Animal Science, University of Minnesota, St. Paul 55108
}

\begin{abstract}
Pure Holsteins ( $\mathrm{n}=380$ ) were compared to Normande/Holstein crossbreds $(\mathrm{n}=245)$, Montbeliarde/ Holstein crossbreds $(\mathrm{n}=494)$, and Scandinavian Red/ Holstein crossbreds $(\mathrm{n}=328)$ for $305-\mathrm{d}$ milk, fat, and protein production during first lactation. Scandinavian Red was a mixture of Swedish Red and Norwegian Red. Cows were housed at 7 commercial dairies in California and calved from June 2002 to January 2005. All Holstein sires and all Holstein maternal grandsires were required to have a code assigned by the National Association of Animal Breeders to assure they were sired by artificial insemination bulls. Daughters of Normande, Montbeliarde, and Scandinavian Red sires were artificial insemination bulls via imported semen. Best prediction was used to calculate actual production (milk, fat, and protein) for 305-d lactations. Adjustment was made for age at calving and milking frequency, and records less than $305 \mathrm{~d}$ were projected to $305 \mathrm{~d}$. Herdyear-season (4-mo seasons) and the genetic level of each cow's Holstein maternal grandsire were included in the model for statistical analysis. Pure Holsteins had significantly higher milk $(9,757 \mathrm{~kg})$ and protein $(305 \mathrm{~kg})$ production than all crossbred groups, but pure Holsteins $(346 \mathrm{~kg}$ ) were not significantly different from Scandinavian Red/Holstein $(340 \mathrm{~kg}$ ) crossbreds for fat production. Fat plus protein production was used to gauge the overall productivity of pure Holsteins vs. crossbreds. The Scandinavian Red/Holstein $(637 \mathrm{~kg})$ crossbreds were not significantly different from the pure Holstein $(651 \mathrm{~kg})$ for fat plus protein production; however, the Normande/Holstein $(596 \mathrm{~kg}$ ) and the Montbeliarde/Holstein crossbreds $(627 \mathrm{~kg})$ had significantly lower fat plus protein production than pure Holsteins. Key words: crossbreeding, heterosis, production
\end{abstract}

\section{INTRODUCTION}

Interest in crossbreeding has been growing among dairy producers over the past $5 \mathrm{yr}$; however, crossbreed-

Received August 22, 2005.

Accepted February 3, 2006.

Corresponding author: hein0106@umn.edu ing of dairy cattle has seldom been practiced over the past $75 \mathrm{yr}$. McAllister (2002) indicated that more than $95 \%$ of US dairy cattle are purebred or grade Holsteins. The superiority of Holsteins for milk production has contributed to a growing global domination of the Holstein breed over time. During recent years, however, milk pricing in most markets has placed greater emphasis on the solids in milk rather than fluid, which resulted in the Holstein breed having less of a competitive advantage compared with other breeds. In a recent survey by Weigel and Barlass (2003), dairy producers cited improvements in fertility, calving ease, longevity, and milk composition as reasons for crossbreeding.

Numerous research studies have documented the potential role of crossbreeding in the dairy industry, but most studies are dated (Fohrman, 1946; Fohrman et al., 1954; Bereskin and Touchberry, 1966; Brandt et al., 1974; Rincon et al., 1982; Touchberry, 1992). A USDA crossbreeding study was initiated in 1939 at Beltsville, MD (Fohrman et al., 1954). Holstein, Jersey, Red Dane, and Guernsey foundation females were bred to Holstein, Jersey, and Red Dane sires to produce 3 generations of crossbreds. Crossbred groups averaged about $30 \%$ more than foundation purebred cows for milk production and about $35 \%$ more for fat production. Using results of Fohrman et al. (1954), Touchberry (1992) estimated heterosis for milk production $(21.6 \%)$ and fat production (18.8\%). Fohrman et al. (1954) concluded "there is sufficient evidence presented here to indicate that female progeny of crossbred cows when sired by production proved bulls will develop into very satisfactory dairy animals."

From 1949 to 1969, a study of crossbreeding of Holsteins and Guernseys was conducted at the University of Illinois. Pure Holsteins were superior to crossbreds for milk production, but crossbreds had an advantage for income per lactation. Income produced per cow per year was $11.4 \%$ greater for crossbreds than the average of the purebreds (Touchberry, 1992).

McAllister et al. (1994) reported greater than $20 \%$ heterosis for lifetime performance in crossbreds of Holstein and Ayrshire. They also reported that moderate heterosis was observed during first lactation for milk, fat, and protein production. In the same crossbreeding 
study at Agriculture Canada, McAllister (1986) indicated that first-lactation crossbreds of Holstein and Ayrshire were not significantly different from pure Holsteins for milk production, but the crossbreds were significantly higher for fat production.

The Animal Improvement Programs Laboratory (AIPL) of USDA conducted an analysis of DHI data to determine breed differences in herds containing both purebred and crossbred cows (VanRaden and Sanders, 2003). In this study, protein production of Brown Swiss/ Holstein crossbreds equaled protein production of pure Holsteins. Fat production was slightly greater for crossbreds of Jersey and Holstein, as well as crossbreds of Brown Swiss and Holstein, than for pure Holsteins. With the milk pricing scenarios Net Merit $\$$ and Cheese Merit $\$$ from USDA, they concluded that first-generation crosses of 2 pure breeds $\left(\mathrm{F}_{1}\right)$, Brown Swiss and Jersey with Holstein, were more profitable than pure Holsteins. In another study with DHI data, Lesmeister et al. (2000) showed Holstein crossbreds could be more profitable than pure Holsteins under commercial conditions.

In New Zealand, crossbreeding has grown substantially in popularity, and numerous studies have been performed to assess the benefits of crossbreeding in pastoral production systems. Ahlborn-Breier and Hohenboken (1991) reported heterosis of $6 \%$ for fat production and 7\% for protein production of crossbreds of Holstein and Jersey compared to the 2 pure breeds. They also noted that $\mathrm{F}_{1}$ crossbreds of Holstein and Jersey were superior to pure Holsteins for fat production. Lopez-Villalobos et al. (2000) evaluated the profitability of alternative breeding systems under New Zealand pastoral conditions. The aim of the study was to evaluate the profitability of dairying under 3 mating systems involving the Holstein-Friesian, Jersey, and Ayrshire breeds. The results suggested that rotational crossbreeding could increase profitability under New Zealand conditions.

A Swedish study (Ericson et al., 1988) determined the effects of crossbreeding the Swedish Red Breed (SRB) and the Swedish Holstein Breed (SLB) on several traits. The $\mathrm{F}_{1}$ offspring of SRB and SLB were superior to pure SRB or SLB for all production traits except lactational milk production.

Crossbreeding might become more advantageous in the future for commercial milk production to avoid the consequences of inbreeding depression as the genetic relationships of the global Holstein population continue to increase. Increase of relationships within dairy breeds is inevitable with continuous selection, especially with BLUP methods for prediction of genetic worth.

\section{Background}

The decline in fertility and survival of pure Holsteins led the managers of 7 large dairies in California to mate Holstein heifers and cows with imported AI semen of the Normande and Montbeliarde breeds from France, as well as the SRB and Norwegian Red Breed (NRF). The SRB and NRF breeds share similar ancestry, mostly Ayrshire and Shorthorn, and exchange sires of sons; therefore, the breeds are collectively regarded as Scandinavian Red (SR) for this study. Crossbred cows began calving in June 2002, and some cows in the 7 dairies continued to be pure Holstein, which permitted comparison of pure Holsteins and crossbreds. Holstein cows were randomly assigned to breed of service sire.

The objectives of this study were to determine differences between pure Holsteins and crossbreds of Normande/Holstein, Montbeliarde/Holstein, and SR/Holstein during first lactation for actual 305-d production of milk, fat, protein, and combined fat plus protein in the 7 commercial dairies in California.

\section{MATERIALS AND METHODS}

\section{Data}

Pure Holstein and crossbred heifers calved from June 2002 to January 2005. Holstein cows were required to be sired by AI sires and have a National Association of Animal Breeders (NAAB) sire code. All sires for the European breed crosses had frozen semen imported into the United States. In addition, the dams of all animals were required to have a Holstein NAAB sire code, which permitted adjustment for production potential of cows according to the genetic merit of their dams. This adjustment should alleviate concerns about nonrandom mating of breeds of sire with individual dams of cows. This edit removed all cows from the study that had natural-service Holstein sires or maternal grandsires.

The number of cows remaining in the data following successive steps of editing is provided in Table 1. Edits were made to test-day observations, and they were similar to those used by the USDA for routine genetic evaluation. Lactations of cows were required to be at least $40 \mathrm{~d}$ in milk. If a cow left the herd, the lactation had to be at least $15 \mathrm{~d}$. A first test day by $90 \mathrm{~d}$ in milk was required. For individual test days, days in milk were required to be from 5 to $365 \mathrm{~d}$. Test days after 305 $\mathrm{d}$ are used to improve prediction of 305-d production (Schaeffer and Jamrozik, 1996). The first test after 305 $\mathrm{d}$, but not beyond $365 \mathrm{~d}$, was included in the data file. Each test day was required to have an observation for milk, fat, and protein production. Fat percentage was required to be at least $1.0 \%$, but no more than $9.9 \%$. Protein percentage was required to be at least $1.0 \%$, 
Table 1. Pure Holstein and crossbred cows remaining after each step of data editing

\begin{tabular}{lllll}
\hline & & \multicolumn{3}{c}{ Crossbreds } \\
\cline { 3 - 5 } Edit & $\begin{array}{l}\text { Pure } \\
\text { Holstein }\end{array}$ & $\begin{array}{l}\text { Normande/ } \\
\text { Holstein }\end{array}$ & $\begin{array}{l}\text { Montbeliarde/ } \\
\text { Holstein }\end{array}$ & $\begin{array}{l}\text { Scandinavian Red/ } \\
\text { Holstein }\end{array}$ \\
\hline First-lactation cows & 1,268 & 494 & 754 & 475 \\
Sire identification & 741 & 443 & 738 & 469 \\
Sample day observations & 738 & 443 & 733 & 467 \\
>40 d in milk & 719 & 437 & 706 & 449 \\
Maternal grandsire identification & 453 & 246 & 497 & 330 \\
Two breed groups per herd-year-season & 380 & 245 & 494 & 328 \\
\hline
\end{tabular}

but no more than $6.0 \%$. Test-day milk weights were required to be $\geq 4.54 \mathrm{~kg}$.

Herd-year-season of calving was based on 4-mo seasons and derived from climatic conditions in California. June, July, August, and September are especially hot months; October, November, December, and January are rainy months; and February, March, April, and May are cool and dry months. With data spanning June 2002 to January 2005, each herd had the potential of contributing 8 year-seasons of calving. However, herdyear-seasons that contained a single breed group were eliminated from the study, and 49 herd-year-seasons had at least 2 breed groups of cows.

Following all edits, 380 pure Holsteins and 245 Normande/Holstein, 494 Montbeliarde/Holstein, and 328 $\mathrm{SR} /$ Holstein crossbreds remained for comparison. The pure Holstein, Normande/Holstein, Montbeliarde/Holstein, and SR/Holstein crossbred cows were daughters of $69,24,23$, and 13 sires, respectively. The 13 SR sires were $4 \mathrm{SRB}$ and $9 \mathrm{NRF}$. The distribution of cows by herd and breed group is in Table 2. The 7 herds were variable in number of cows and in extent of use of crossbreeding. Only 20 cows passed edits from herd 5, however, these observations were spread across only 4 herdyear-seasons, so they contributed meaningful information for breed group comparisons.

\section{Genetic Level of Sires of Cows}

Historically, the 7 California dairies used high-ranking Holstein sires for production. The weighted mean

Table 2. Distribution of pure Holstein and crossbred cows by heard and breed group

\begin{tabular}{|c|c|c|c|c|}
\hline \multirow[b]{2}{*}{ Herd } & \multirow[b]{2}{*}{$\begin{array}{l}\text { Pure } \\
\text { Holstein }\end{array}$} & \multicolumn{3}{|c|}{ Crossbreds } \\
\hline & & $\begin{array}{l}\text { Normande/ } \\
\text { Holstein }\end{array}$ & $\begin{array}{l}\text { Montbeliarde/ } \\
\text { Holstein }\end{array}$ & $\begin{array}{l}\text { Scandinavian Red/ } \\
\text { Holstein }\end{array}$ \\
\hline 1 & 214 & 13 & 7 & 59 \\
\hline 2 & 47 & 58 & 93 & 82 \\
\hline 3 & 3 & 27 & 40 & 25 \\
\hline 4 & 68 & 73 & 179 & 79 \\
\hline 5 & 0 & 3 & 3 & 14 \\
\hline 6 & 12 & 40 & 84 & 18 \\
\hline 7 & 36 & 31 & 88 & 51 \\
\hline
\end{tabular}

PTA of the 69 sires of the pure Holstein cows in this study were $+257 \mathrm{~kg}$ of milk, $+6 \mathrm{~kg}$ of fat, and $+8 \mathrm{~kg}$ of protein from the May 2005 genetic evaluation on the PTA05 stepwise genetic base of USDA. The sires of cows in this study were used as service sires of dams from 1999 to 2002. The mean PTA of active AI Holstein bulls in the United States in May 2000 (Animal Improvement Programs Laboratory, 2000) were $+196 \mathrm{~kg}$ of milk, $+6 \mathrm{~kg}$ of fat, $-1 \mathrm{~kg}$ of protein. Therefore, the weighted means for PTA of milk, fat, and protein production for the 69 Holstein sires were above average at time of use. The weighted mean PTA for the 23 Normande sires $(+158 \mathrm{~kg}$ of milk, $+7 \mathrm{~kg}$ of fat, $+8 \mathrm{~kg}$ of protein) and the 24 Montbeliarde sires $(+81 \mathrm{~kg}$ of milk, $+3 \mathrm{~kg}$ of fat, $+10 \mathrm{~kg}$ of protein) were from the January 2005 genetic evaluations from the National Institute for Agricultural Research (INRA) in France. France uses a rolling genetic base, and the PTA of the Normande and Montbeliarde sires suggest that they were respectable, but perhaps not the highest, within breed for production at the time of use by the California dairies. The weighted mean PTA of the 13 SR sires were obtained from the May 2005 Interbull Ayrshire evaluation on the US genetic base $(+569 \mathrm{~kg}$ of milk, $+24 \mathrm{~kg}$ of fat, $+22 \mathrm{~kg}$ of protein). Subtraction of onehalf of the difference of the PTA05 Ayrshire and Holstein breed genetic bases in the United States provides estimates $(-1,047 \mathrm{~kg}$ of milk, $-26 \mathrm{~kg}$ of fat, $-21 \mathrm{~kg}$ of protein) of the $13 \mathrm{SR}$ sires on the PTA05 Holstein genetic base.

\section{Lactation Curves of Cows}

Actual sample-day production for milk and fat (kg) plus protein $(\mathrm{kg})$ was used to provide a preliminary assessment of the lactation curves of breed group. Sample-day production across 20 -d intervals ( 5 to 24,25 to 44 , etc.) postpartum was adjusted for fixed effects age of calving (linear and quadratic), herd-year-season, and breed group with the GLM procedure of SAS (SAS Institute, 2004). All fixed effects were significant $(P<0.01)$. The GPLOT procedure of SAS (SAS Institute, 2004) was then used to plot lactation curves with a cubic 


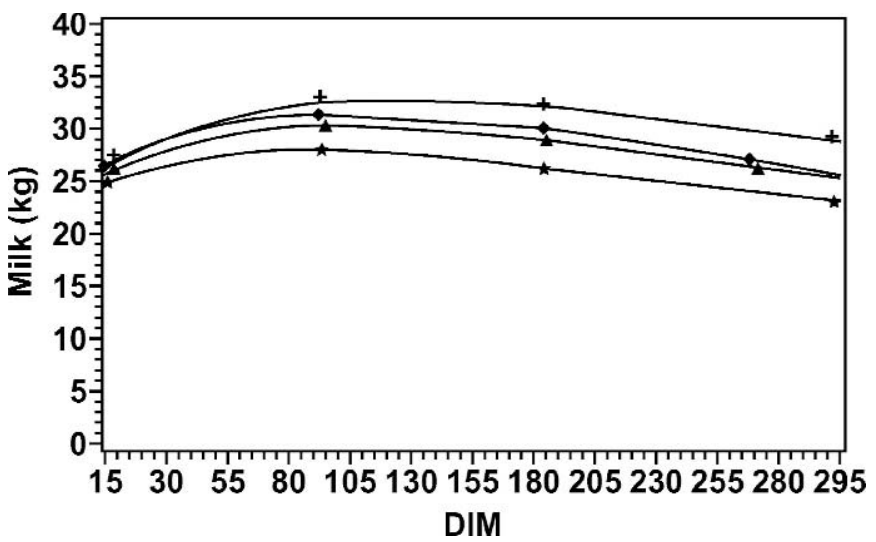

Figure 1. Lactation curves for pure Holsteins (+) and Normande/ Holstein $(\star)$, Montbeliarde/Holstein $(\boldsymbol{\Delta})$, and Scandinavian Red/Holstein $(\diamond)$ crossbreds for milk (kg).

spline method for smoothing. Figure 1 has lactation curves for milk $(\mathrm{kg})$ and Figure 2 has lactation curves for fat $(\mathrm{kg})$ plus protein $(\mathrm{kg})$ for pure Holsteins and Normande/Holstein, Montbeliarde/Holstein, and SR/ Holstein crossbred cows. The production curves in both Figures 1 and 2 suggest that breed groups were similar for persistency of production through lactation.

\section{Best Prediction of Production}

Actual milk, fat, and protein production for 305-d lactations was calculated with best prediction (BP), which was implemented by AIPL in February 1999 for national genetic evaluation in the United States (VanRaden, 1997). For the previous $30 \mathrm{yr}$, the test interval method and projection factors were used to calculate lactation records in the United States. When compared

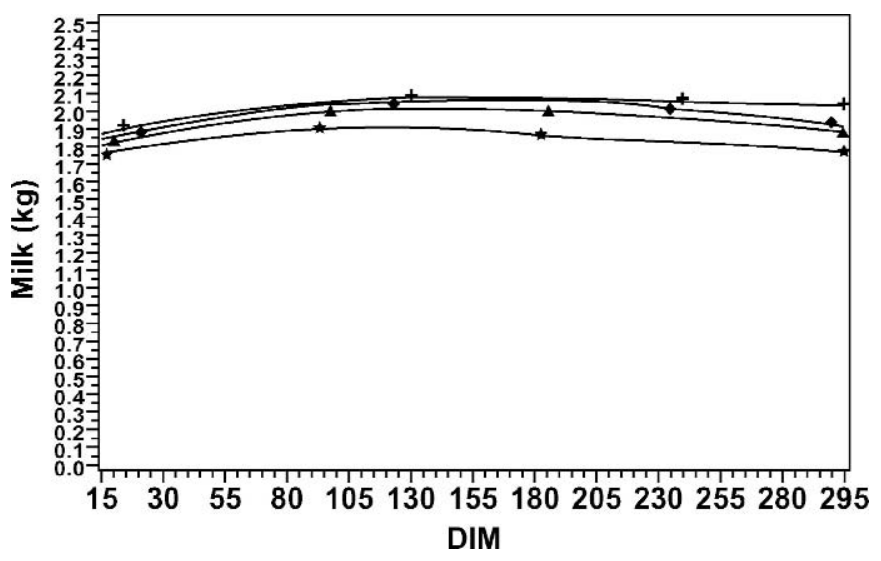

Figure 2. Lactation curves for pure Holstein $(+)$ and Normande/ Holstein ( $\star$ ), Montbeliarde/Holstein $(\boldsymbol{\Delta})$, and Scandinavian Red/Holstein $(\diamond)$ crossbreds for fat plus protein $(\mathrm{kg})$. to the test interval method, BP more accurately predicts lactational production (Norman et al., 1999). With BP, information is condensed from many test days into optimal lactation measures of production and persistency. Lactational production is the sum of daily measured or predicted production. For lactations less than $305 \mathrm{~d}$, daily production before the current test day is summed by BP; then, $\mathrm{BP}$ extends the lactation curve to $305 \mathrm{~d}$ by extrapolation. Furthermore, BP uses mean production level of each herd to improve the accuracy of prediction.

A BP algorithm was obtained from Agri-Tech Analytics (Visalia, CA), and was based on the BP methods used by AIPL of USDA. The BP was applied separately to each of the 7 dairies in this study and herd-specific lactation curves were used to calculate 305-d actual production. Also, BP adjusted for age at calving and milking frequency with factors developed by AIPL. Production from test days for cows milked 3 times daily was adjusted to twice-daily milking. Records less than $305 \mathrm{~d}$ were projected to $305 \mathrm{~d}$.

\section{Statistical Analyses}

Dependent variables for the statistical model were 305-d milk, fat, and protein production, as well as fat plus protein production, from BP. Independent variables were effects of herd-year-season, breed group, and linear regression on the PTA of each cow's maternal grandsire. The PTA for the respective production trait of the cow's maternal grandsire was included as a covariable in the analysis to account for the genetic level of dams of cows. The PTA for production traits were obtained from the May 2005 genetic evaluation of USDA via the AIPL website (http://aipl.arsusda.gov/). The GLM procedure of SAS (SAS Institute, 2004) was used to obtain solutions and conduct the ANOVA.

\section{RESULTS AND DISCUSSION}

Herd-year-season and breed group were significant $(P<0.01)$ for all production traits. The PTA of the maternal grandsire was significant $(P<0.01)$ for only the production trait of milk. The solutions for linear regression of the PTA of maternal grandsire on milk, fat, protein, and fat plus protein production were 0.39 $\pm 0.15,0.17 \pm 0.12,0.24 \pm 0.14$, and $0.20 \pm 0.14$, respectively, with expectations of 0.50. Explanations for lower than expected regression coefficients are unknown; however, the solutions in this study are similar to those found by Cassell et al. (1983). Nonetheless, the inclusion of the covariable should have accounted for differences of genetic potential for production of dams of cows.

Table 3 shows probability levels for contrasts of pure Holsteins versus crossbreds for production, and Table 
Table 3. Probability levels for contrasts of pure Holsteins versus crossbreds for $305-\mathrm{d}$ actual production during first lactation

\begin{tabular}{llllll}
\hline & & \multicolumn{3}{c}{ Probability from $F$-statistic } \\
\cline { 3 - 6 } Breed 1 & Breed 2 & Milk & Fat & Protein & Fat + Protein \\
\hline Pure Holstein & Normande/Holstein & $* *$ & $* *$ & $* *$ & $* *$ \\
Pure Holstein & Montbeliarde/Holstein & $* *$ & $* *$ & $* *$ & $* *$ \\
Pure Holstein & Scandinavian Red/Holstein & $* *$ & & $*$ & \\
\hline$* * P<0.01 ; * P<0.05$ & & & &
\end{tabular}

4 shows least squares means and standard errors for breed groups. Pure Holstein cows $(9,757 \mathrm{~kg})$ were superior $(P<0.01)$ to all of the crossbred groups for milk production, which is consistent with the results of Touchberry (1992) and McAllister et al. (1994).

For fat production, pure Holstein cows $(346 \mathrm{~kg})$ were significantly higher $(P<0.01)$ than Normande/Holstein $(319 \mathrm{~kg})$ and Montbeliarde/Holstein $(334 \mathrm{~kg})$ crossbred cows; however, pure Holstein cows were not different $(P>0.05)$ from SR/Holstein $(340 \mathrm{~kg})$ crossbreds for fat production. The fat percentages were $3.55,3.74,3.64$, and $3.66 \%$, respectively, for the pure Holsteins and Normande/Holstein, Montbeliarde/Holstein, and SR/Holstein crossbred cows. Results for fat production agree with those of Rincon et al. (1982), who found Ayrshire/ Holstein and Brown Swiss/Holstein crossbreds had higher fat percentages and similar fat production compared to pure Holsteins.

For protein production, Holsteins (305 kg) were significantly higher $(P<0.01)$ than Normande/Holstein $(277 \mathrm{~kg})$ and Montbeliarde/Holstein $(293 \mathrm{~kg})$ crossbreds. Pure Holsteins also surpassed the SR/Holstein $(297 \mathrm{~kg})$ crossbreds for protein production, but at a lower level of significance $(P<0.05)$. Protein percentage for the pure Holsteins was $3.13 \%$ compared to $3.24 \%$ for Normande/Holstein crossbreds, 3.20\% for Montbeliarde/Holstein crossbreds, and $3.20 \%$ for SR/Holstein crossbreds.

Fat $(\mathrm{kg})$ plus protein $(\mathrm{kg})$ was used to gauge the overall productivity of pure Holsteins vs. crossbreds. Pure Holsteins $(651 \mathrm{~kg})$ were significantly higher $(P<0.01)$ than the Normande/Holstein $(596 \mathrm{~kg}$ ) and the Montbeliarde/Holstein $(627 \mathrm{~kg})$ crossbreds for fat plus protein production. On a percentage basis, the Normande/Hol- stein crossbreds had $8.6 \%$ less fat plus protein production than pure Holsteins. The Montbeliarde/Holstein crossbreds $(-3.8 \%)$ were much closer to the pure Holsteins for fat plus protein production, and the SR/Holstein crossbreds $(-2.2 \%)$ did not differ significantly $(P$ $>0.05$ ) from pure Holsteins. The mating system did not permit the separation of additive genetic and heterotic effects.

The means of breed groups for 305-d production in this study were not adjusted for differences in days open for cows. Days open in current lactation has been documented to have a significant effect on lactational production (Lee et al., 1997); however, appropriate adjustment for current days open is difficult. Fewer days open causes decreased lactational production, but increased lactational production causes more days open. Consequently, the cause-and-effect relationship of lactational production and reproductive status is not easily disentangled. Appropriate adjustment for breed group differences in days open might bring the production of the crossbred groups closer to the production of pure Holsteins. The major reason that dairy producers in this study were exploring the potential of crossbreeding was to improve the fertility, health, and survival of cows.

\section{CONCLUSIONS}

Pure Holsteins in this study had significantly higher 305-d milk and protein production than all crossbred groups; however, pure Holsteins were not significantly different from SR/Holstein crossbreds for fat production. The SR/Holstein crossbreds $(-2.2 \%)$ were not significantly different from the pure Holstein for fat plus

Table 4. Least squares means and standard errors for 305-d actual production during first lactation of pure Holsteins and crossbreds

\begin{tabular}{|c|c|c|c|c|c|}
\hline Breed & $\mathrm{n}$ & Milk & Fat & Protein & Fat + Protein \\
\hline & & & - & & \\
\hline Pure Holstein & 380 & $9,757 \pm 101.6$ & $346 \pm 3.6$ & $305 \pm 3.0$ & $651 \pm 6.4$ \\
\hline Normande/Holstein & 245 & $8,530 \pm 89.8$ & $319 \pm 3.2$ & $277 \pm 2.7$ & $596 \pm 5.6$ \\
\hline Montbeliarde/Holstein & 494 & $9,161 \pm 76.8$ & $334 \pm 2.7$ & $293 \pm 2.3$ & $627 \pm 4.8$ \\
\hline Scandinavian Red/Holstein & 328 & $9,281 \pm 76.6$ & $340 \pm 2.8$ & $297 \pm 2.4$ & $637 \pm 5.0$ \\
\hline
\end{tabular}


protein production; however, the Montbeliarde/Holstein $(-3.8 \%)$ and the Normande/Holstein $(-8.6 \%)$ crossbreds were significantly lower $(P<0.01)$ than the pure Holsteins for fat plus protein production.

No adjustment was made to production for differences in days open of cows. Cows with fewer days open are penalized for 305-d production. Therefore, if appropriate adjustment for days open had been possible, production of crossbreds might have been closer to that of pure Holsteins. Crossbreeding of dairy cattle is being explored mostly for its potential to improve the fertility, health, and survival of cows, and advantages for these traits might compensate for loss in production of crossbreds compared to pure Holsteins.

\section{ACKNOWLEDGMENTS}

The authors express appreciation to Agri-Tech Analytics (Visalia, CA) for the use of their BP algorithm to calculate lactational production. Furthermore, the authors wish to thank Jerry Steuernagel for his assistance in implementing the $\mathrm{BP}$ algorithm. The authors are especially grateful to the managers of the 7 California dairies, who willingly provided data from their cows. Without their cooperation, this study would not have been possible.

\section{REFERENCES}

Ahlborn-Breier, G., and W. D. Hohenboken. 1991. Additive and nonadditive genetic effects on milk production in dairy cattle: Evidence for major individual heterosis. J. Dairy Sci. 74:592-602.

Animal Improvement Programs Laboratory. 2000. Summary of May 2000 Evaluations. Online. Available ftp://aipl.arsusda.gov/pub/ bulls/0005.evalrpt Accessed Aug. 16, 2005.

Bereskin, B., and R. W. Touchberry. 1966. Crossbreeding dairy cattle. III. First-lactation production. J. Dairy Sci. 49:659-667.

Brandt, G. W., C. C. Brannon, and W. E. Johnston. 1974. Production of milk and milk constituents by Brown Swiss, Holsteins, and their crossbreds. J. Dairy Sci. 57:1388-1393.

Cassell, B. G., A. J. Seykora, and B. T. McDaniel. 1983. Effects of adjustment for mate's yield, mate's sire merit, and days open in sire evaluation. J. Dairy Sci. 66:601-611.
Ericson, K., B. Danell, and J. Rendel. 1988. Crossbreeding effects between two Swedish dairy breeds for production traits. Livest. Prod. Sci. 20:175-192.

Fohrman, M. H. 1946. A cross-breeding experiment with dairy cattle. BDIM-INF-30. USDA, Bureau of Dairy Industry, Washington, DC.

Fohrman, M. H., R. E. McDowell, C. A. Matthews, and R. A. Hilder. 1954. A crossbreeding experiment with dairy cattle. Tech. Bull. 1074, USDA, Washington, DC.

Lee, J. K., P. M. VanRaden, H. D. Norman, G. R. Wiggans, and T. R. Meinert. 1997. Relationship of yield during early lactation and days open during current lactation with 305-day yield. J. Dairy Sci. 80:771-776.

Lesmeister, K. E., A. H. Kellogg, A. H. Brown Jr., Z. B. Johnson and A. G. Lane. 2000. Effects of crossbreeding and season of calving on production of milk fat and protein of primiparous dairy cows. J. Dairy Sci. 83(Suppl. 1):52 (Abstr.)

Lopez-Villalobos, N., D. J. Garrick, C. W. Holmes, H. T. Blair, and R. J. Spelman. 2000. Profitabilities of some mating systems for dairy herds in New Zealand. J. Dairy Sci. 83:144-153.

McAllister, A. J. 1986. The role of crossbreeding in breeding programs for intensive milk production in temperate climates. Proc. 3rd World Congr. Genet. Appl. Livest. Prod., Lincoln, NE. IX:47-61.

McAllister, A. J. 2002. Is crossbreeding the answer to questions of dairy breed utilization? J. Dairy Sci. 85:2352-2357.

McAllister, A. J., A. J. Lee, T. R. Batra, C. Y. Lin, G. L. Roy, J. A. Vesely, J. M. Wauthy, and K. A. Winter. 1994. The influence of additive and nonadditive gene action on lifetime yields and profitability of dairy cattle. J. Dairy Sci. 77:2400-2414.

Norman, H. D., P. M. VanRaden, J. R. Wright, and J. S. Clay. 1999 Comparison of test interval and best prediction methods for estimation of lactation yield from monthly, a.m.-p.m., and trimonthly testing. J. Dairy Sci. 82:438-444.

Rincon, E. J., E. C. Schermerhorn, R. E. McDowell, and B. T. McDaniel. 1982. Estimation of genetic effects on milk yield and constituent traits in crossbred dairy cattle. J. Dairy Sci. 65:848-856.

SAS Institute. 2004. SAS/STAT Software. Release 9.1.3. SAS Inst., Inc., Cary, NC.

Schaeffer, L. R., and J. Jamrozik. 1996. Multiple-trait prediction of lactation yields for dairy cows. J. Dairy Sci. 79:2044-2055.

Touchberry, R. W. 1992. Crossbreeding effects in dairy cattle: The Illinois Experiment, 1949 to 1969. J. Dairy Sci. 75:640-667.

VanRaden, P. M. 1997. Lactation yields and accuracies computed from test day yields and (co)variances by best production. J. Dairy Sci. 80:3015-3022.

VanRaden, P. M., and A. H. Sanders. 2003. Economic merit of crossbred and purebred US dairy cattle. J. Dairy Sci. 86:1036-1044.

Weigel, K. A., and K. A. Barlass. 2003. Results of a producer survey regarding crossbreeding on US dairy farms. J. Dairy Sci. 86:4148-4154. 